NEW LITERARIA-

An International Journal of Interdisciplinary Studies in Humanities

Volume 3, No. 1, January-February, 2022, PP. 01-15

ISSN: 2582-7375

DOI: https://dx.doi.org/10.48189/nl.2022.v03i1.001

www.newliteraria.com

\title{
The Past, the Present, and the Future: Memory and Literature as Gateways from the Middle Ages to the Twenty-First Century With a focus on Boethius's De Consolatione Philosophiae and Wolfram von Eschenbach's Parzival
}

\author{
Albrecht Classen
}

\begin{abstract}
The crucial question we are facing today in the Humanities pertains to the issue of how we engage with the past and how we converse with literary or philosophical voices from the Middle Ages, for instance, and recover their relevance for us today. This paper examines the meaning of cultural history at first and then turns to two major voices from the past to illustrate the central concern, first the late antique philosopher Boethius (d. 525), then Wolfram von Eschenbach (active ca. 1200-1220). Both endeavored to explore the meaning of human life and offered intriguing perspectives that appear to have timeless value. Whereas Boethius investigated the issue of how the individual can productively face or dismiss mis/fortune and thereby gain an understanding of the true meaning of happiness, Wolfram outlined in his Grail romance Parzival how the human individual must forge his/her path through life in order to discover the true goal of one's self. While the future is waiting for us, we can prepare ourselves by listening to those past voices as guides through all existence.
\end{abstract}

Keywords: Past and present, Timeless Humanities, Boethius, Wolfram von Eschenbach, Path through Life, Relevance of Literature, Philosophy.

\section{Introduction}

Anyone who wants to offer a solid contribution to the discourse on the Humanities today and in the future, must be thoroughly aware of the deep history of that discourse, must understand how much we as human beings are historical beings, and that we live to a large extent on the basis of our memory, our culture, our traditionally developed ideals, and values, and hence draw in many different ways from the past as the foundation for everything we are, we do, we dream of, desire, and hope for. While the future is imminently waiting for us, it is also critically dependent on the other side of the bridge reaching out from the past. If this metaphor holds, we could claim that we are, today, the keystones of that bridge, relying on the countless insights and experiences from the past which have helped us to cross the first part of the river of time, and then moving forward to the other side of the river, walking, gliding, or stumbling along that slippery path. But whatever river it might be, whatever bridge we might erect and use, there always have to be two bridgeheads, and the keystone, us.

A simple example that illustrates all that in a striking fashion is our language, the basic means of communication, which is a tool we have acquired in the course of time, which each new individual has to learn after birth, and which we can operate with to an incredible degree 
of creativity and freedom throughout our lives. Without language there is no existence, though we do not necessarily need words to communicate. And all languages are historically determined and mirror intimately our cultural identity, that is, our growth as a social collective over hundreds and thousands of years. Similarly, the food we eat, the clothes that we wear, our treatment of the elder and children, the attitude between the genders etc. are all historically grown and steeped in old traditions, though not caught by them either. Those traditions break at times, of course, leading to paradigm shifts, but in most cases only on the surface, not in their historical foundation.

By contrast, a purely conservative approach to our existence, idealizing our history at all costs, denying the value of the present and despising the imminent future could be the death knell for our progress since we live by way of growth, of learning, adapting, experimenting, studying, exchanging, and marching along toward a hopefully better future. But the tomorrow is not a guarantee for improvement since history is not automatically progressive. The twentieth century witnessed incredible political changes, technical innovations, and revolutionarily new media, but it also witnessed two world wars, the Holocaust, the Korea, and the Vietnam War, and, worst of all, the rise of the atomic age (nuclear bombs on Hiroshima and Nagasaki in 1945 !).

We could argue, for instance, that all life can be described in terms of a forest, with a bed of roots, the tree trunks above, the branches, the leaves, with the entire organism both in itself and in close cooperation with all other plants/beings creating a form of synergy of a universal kind (Classen, 2020). However, the present generation all over the world seems to move away from history as something irrelevant and incomprehensible, as numerous critics have warned us about, mostly intrigued by the futuristic computational possibilities of a robotic age based on AI. By the same token, we have reached the current stage of human development only by keeping one eye on the past and one eye on the future. Whether people forget history or not, it, that is, the values, ideas, and experiences, will always remain with us, will never leave us alone, and will continue to impact itself on us. Irrespective of our like or dislike of the past, it is like our shadow, and we better engage with it constructively so we can utilize its energy (positive or negative) for us to build our future (Arnold, 2021, p. 8-22).

Neglecting our history would be tantamount to ignoring the basic skills of driving a motor vehicle and relying on a computer to steer the car instead (Carr, 1961; Breisach, 1963; Feyerabend, 1989; Southern, 2004; Banner, 2012; et al.). Most of our current problems, whether climate change or massive migrations, whether Antisemitism or Islamophobia (Kohen and Steinacher, 2021), can only be approached and studied, hence can be engaged with constructively if we remember their historical origins and conditions. The same applies, of course, to Philology (Davetsian, 2009/2017) or Philosophy, that is, to the Humanities at large (Classen, 2017; Classen, 2018).

\section{Humanities Today and Tomorrow}

The entire academic field of Historical Studies, but then also Classics, and the Modern Languages are hence deeply concerned with this question of how they can maintain their status within the academy in the face of postmodern concerns and values. The purpose of this paper is, however, not focused on the historical dimension as such, but on the question of how we establish and maintain relevance and meaning in the modern world. I will have to ignore many different approaches pursued so far, leaving aside specifically historical aspects in the narrow sense of the word, and will, instead, turn my attention to a philosophical-literary discourse that 
runs in a thick and deep stream through our bodies and minds (Zunshine, 2006; Kydd and Castano, 2013; Oatley, 2016). After all, as Michael Calabrese reminds us in his new translation of William Langland's Piers Plowman,

Piers, though a nearly 700-year-old poem, can reach the human heart of readers today in the twenty-first century, just as we imagine it must have in its own time. The poem asks eternal questions that pertain not only to Christians but to all communities. Readers of different world faiths, or no faith at all, will engage with its ethical challenges, for Piers depicts not only the quest for salvation but also the hunger for justice here and now on erth, in society, clergy, and government. (1)

We could apply this observation to many pre-modern narratives and poems, especially because the authors or poets were very much on their journey, and our lives today continue to be determined by journeys (Classen, Tracing, 2021, 22-26). Most people would not hesitate to approve history as a fairly important subject matter in general terms, and the internet is actually filled with blogs and websites where we find a wide gamut of relevant comments on this issue, highlighting aspects such as cultural identity, memory, moral and ethical concerns from the past for the present, the growth of good citizenship, understanding the reasons for the way who and why we are, and the investigation of our current political structure (e.g., https://www.arcadiapublishing.com/Navigation/Community/Arcadia-and-THP-Blog/June2016/Why-It\%E2\%80\%99s-Important-That-We-Study-History; https://archives.history.ac.uk/makinghistory/resources/articles/why_history_matters.html; https://www.historians.org/about-aha-and-membership/aha-history-and-archives/historicalarchives/why-study-history-(1998); https://www.uopeople.edu/blog/why-is-historyimportant/; all last accessed on Oct. 24, 2021). In theory, history is all good, particularly for hobby historians, also for us at large, but in practice, we are in danger of losing the connection to it and might hence be condemned to repeat it, as George Santayana had famously formulated it (Santayana, 1905). Without memory, personal reflections, deep insights into our own past and that of other people, humanity is at risk to fall into an abyss of fascism, dictatorship, and/or of the collapse of our natural environment.

\section{Universal Values and Ideals}

To restate the obvious, and this for very specific purposes, despite countless changes in language, religion, culture, mentality, and material conditions, there are universal values and ideals in all of human life. Even though the Ten Commandments or the Golden Rule, for instance, are often associated with the western world, they certainly find reflections in the eastern world as well, irrespective of slightly different approaches. Ethics and morality are of timeless and global relevance, which implies that we can trust the significance and relevance of a tenth-century Chinese ballad or epic poem as much as those of a twelfth-century Icelandic saga or an early modern African epic poem. Just as much as music possesses a certain universality and relevance (Classen, "Music," 2021), as much does the literary work in its constant exploration of human imagination, irrespective of countless manifestations that change all the time.

The history of mentality also demonstrates that people all over the world pursue very similar, if not even identical concepts and are influenced by parallel notions, sentiments, and values (Dinzelbacher, ed., 1993/2008). This is not to deny huge differences between the history and culture of Japan, for instance, on the one hand, and of Brazil, on the other. Or the differences between medieval and modern responses to emotions and expressions of feelings (Broomhall, ed., 2015; Rosenwein and Cristiani, 2018; Barclay, 2020). Humankind is highly diverse and colorful, and yet, the foundations, the roots, are, after all, very similar, particularly in their functions. Otherwise, we would not be able to appreciate art and philosophy as such; we would not be able to exchange in goods; and we would not be able to share a dinner together. 
The human being needs safety, shelter, food, and love, and it can only exist, to formulate it globally, if there is justice and peace, if laws are in place to protect all, and if ethics and morality are observed by the vast majority of people.

Intriguingly, the last points, combined with the religious component, were already expressed by the Middle High German poet Walther von der Vogelweide (ca. 1190-ca. 1220) who in his first Imperial Stanza ("Reichsspruch") expressed his deep concerns with the question how an individual could earn money, worldly fame, and God's love altogether. In his "Ich sazûfeimesteine" (no. 27: I sat upon a boulder) he warns his audience that it would be near impossible to combine all three since they are in direct conflict with each other: "dazdickeeinanderschadentuot" (12; which often do each other harm). Moreover, even the effort to bring them together would be made most difficult because disloyalty and violence rule the day (21-22). However, once peace and justice would be reinstalled, then there might be hope for the individual to enjoy material wealth, worldly fame, and God's love all in one (Walther, 2003, 140-41; cf. also Walther von der Vogelweide, 2013; for a general introduction, see Ehrismann, 2008; Reichert, 1992/2009).

In fact, many medieval poets, whether they created didactic narratives or philosophically tinged romances, whether they explored the issue of love or the meaning of God, continue to speak to us richly and meaningfully, so our metaphor of the tree, with the roots representing our past and the canopy representing our present, proves to be very effective (Medieval Answers to Modern Problems, 2012/2017). However, before we proceed with our systematic approach to the issue at hand, let us outline what the central concerns have always been and what scholars in the Humanities will continue to struggle with. Of course, it makes good sense that contemporary authors and scholars address primarily such burning issues as racism, agism, sexism, misogyny, migration, environmental crisis, war, and the quest for the individual.

Some of those topics were of relevance in the pre-modern period as well, but the dominant themes were of more fundamental concerns: the meaning of life and death, the quest for God, love, the quest itself, in a religious and a secular context, and the search for happiness, and this in a philosophical, religious, and literary framework. Happiness, here not meaning a personal joy, or pleasure, but a deeper meaning of identity and relevance, whether in a spiritual or in a pragmatic sense of the word, constitutes probably the most critical ideal which virtually all medieval and early modern poets pursued in their works (Powell, 1992/2016; Classen, 2016; Contreras-Vejar, Jen, and Turner, ed., 2019; Classen, "Happiness," 2021). Following, I will highlight some of the most influential poets and writers from late antiquity to the early modern age, as fragmentary as these remarks might be, so as to create a chain of intellectual thoughts connecting the past with the present and thus to establish a foundation for our future in a universal sense. Little wonder, for instance, that we have discovered in recent years the phenomenon of race before racism, pervasive homophobia, deeply anchored sexism and misogyny, and antisemitism, among many other problems. Those continue to be with us, and we must confront them both with the help of a historical and a contemporary lens (regarding race, see, e.g., Dagenais and Greer, 2000; Heng, 2018; Kaplan, 2019; Seth, 2020).

\section{Boethius: A Late Antique Voice}

\section{Mis/fortune and Happiness: The Universal Quest for Happiness}

It would be virtually impossible to identify any intellectual or philosopher who would have exerted a greater influence on the entire pre-modern world than Boethius (d. ca. 525). He was 
innocently imprisoned on trumped-up charges of state treason and eventually stoned to death. But just in time before his execution, he composed his famous dialogue treatise, Consolatiophilosophiae in which the speaker finds himself stuck in prison, suffering badly from the injustice of his destiny, when the allegorical figure of philosophy appears and engages him in a lengthy exchange about the meaning of human life, the property of fortune and misfortune, and especially about true happiness. This Consolation of Philosophy became one of the most influential works ever created in late antiquity, and we can hardly fully assess the true number of copies, translations, and adaptations of this work (Boethius, 1969).

Although most young readers are not familiar with it, and this anywhere in the world, any exposure to Boethian thinking always yields enthusiastic responses. The reasons for this reaction are not hard to fathom because the protagonist suffers from injustice and is desperate to figure out his life, for which Philosophy has to provide him with basic teachings once again; in fact, as she realizes, he has forgotten what he once had learned, and needs to be reminded by her what it all means to be human and what true happiness might mean (cf., for instance, Marenbon, ed., 2009).

As Boethius has to realize quickly, and we can easily follow him in that regard, almost all forms of worldly happiness are nothing but self-deception. Material wealth, political power, fame, family, and even friendship tend to be temporary and evanescent; as is perhaps best illustrated by wealth, which makes the rich person extremely fearful and requires constant protection. And, no one is ever able to take that wealth with him/her to the grave. Friendship, by contrast, might be an everlasting value, but one learns about its true character only in the time of misfortune. Thus, fortune would be a deceiver, whereas misfortune facilitates the realization of truth, such as about one's friendship. Fortune by itself is defined by the wheel, hence the continuous change and the unreliability of every situation or condition here in this life. Once the individual has realized this fact, s/he can finally try to move beyond the wheel of fortune and begin to strive for true happiness. It would go too far here to trace the philosophical musings in this treatise, so suffices it for us to note that there cannot be true happiness in this life because we are material beings and will always experience a shortcoming, hence suffering.

However, as philosophy then teaches, there is a dimension of true happiness, which rests only in one being that is self-sufficient, independent, all powerful, hence in the creator of all, the summum bonum. The human individual or any other creature can only strive toward that goal of achieving self-sufficiency, but it will never fully reach it until it has merged with that Goodness/Godhead fully, which is far beyond all our human comprehension. But Philosophy offers at least one fundamental metaphor to illustrate the meaning of her lesson. She refers to plants, even to rocks, and emphasizes that every creature, every being, wants to realize all of its potentials, wants to be in the best possible manner, and no plant would hence deliberately try to grow under the worst conditions. On the contrary, all beings aim for their maturity, which thus translates into a sense of complete independence, or self-sufficiency.

In other words, all beings need to develop their full potentiality and become themselves, which automatically means aiming for the highest being and merging with it in order to partake in its absolute, ultimate, and eternal power, unity, harmony, and inner freedom. As we learn from Philosophy as a kind of summary of her own teaching: "So that all things seek the good, which you could describe by saying that it is goodness itself which all things desire" (Book III,ch. XI, p. 108). Boethius insists, through this allegorical figure, that true happiness rests in the quest to move beyond the confines of mis/fortune and to search for inner freedom, that is, sufficiency, self-contentment, hence power, unity, and harmony: 
all that exists is in a state of unity and that goodness itself is unity; from which it follows that we must see everything that exists as good. This means that anything which turns away from goodness ceases to exist, and thus that the wicked cease to be what they once were. . . . Now, since only goodness can raise a man above the level of human kind, it follows that it is proper that wickedness thrusts down to a level below mankind those whom it has dethroned from the condition of being human. (Book IV, ch. III, p. 125).

\section{The Medieval Quest}

We could easily expand from here and discuss an almost infinite number of medieval philosophers and theologians, poets and artists, composers and sculptors who all addressed in their own way and their own media the ultimate question of what the meaning of all human life might be and how we as individuals might manage to find our way toward a rather elusive goal (Classen, Tracing, 2021). Our existence is, after all, a continuous journey, and while we are forging ahead in our own lives, all travelers throughout time have followed previously blazed paths, here leaving aside the few original pathfinders, of course, but all have been on their way and will continue to do so in the future (Moor, 2016). There are actually countless literary examples from our own day and age of the travel as a symbol of human existence, but for my purposes, I suggest to turn our attention to one of the greatest courtly romances where this phenomenon comes through quite powerfully. I could, of course, engage specifically with Dante Alighieri's Divina Commedia (ca. 1320) or Guillaume de Deguileville (1295-before 1358)'s Le Pèlerinage de la Vie Humaine, Le Pèlerinage de l'Âme, and Le Pèlerinage de Jhesucrist, some of the most famous and highly popular texts from the late Middle Ages. I prefer, however, to engage her with another text that has not received sufficient interest outside of German-language research, Wolfram von Eschenbach's Parzival (ca. 1205).

\section{Wolfram von Eschenbach's Parzival}

Germanist scholars would not need any introduction to Wolfram von Eschenbach, one of the best-known names in the annals of medieval German literature. But in our context, particularly his Parzival proves to be most meaningful and deserves close analysis not just for its own sake, but particularly as a monumental literary masterpiece from the past which continues to appeal to us to probe the critical issues in all of human existence (Wolfram von Eschenbach, 1998; Wolfram von Eschenbach, 2004/2006). Consisting of 827 books, or chapters, and each one of 30 verses, it would not be possible here to go too much into details. But we can easily grasp the essential message dealt with in the major section in which we follow the protagonist's life, after his father Gahmuret's death in warfare somewhere in the Middle East, where he had originally married a black queen, Belacane, which resulted in the birth of a bi-racial child, Parzival's half-brother Feirefiz. Parzival's mother, Herzeloyde, is so grieved over the death of her husband that she retires into a sylvan solitude in the hope to raise her son free from all temptations of the courtly world and of knighthood.

She fails in that regard, of course, and young Parzival leaves this hermitage without care about his mother, who dies, however, from a broken heart once he has departed. He will learn about that tragedy only much later, once his learning process has set in, although this takes various stages and teachers. And only when he has spent time with his uncle Trevrizent, does he finally understand the consequences of his previous actions, comprehends the need to pursue a spiritual path, and gains insight into the most important lesson in human life, humility and humbleness in face of both the sacred and the profane dimension (for helpful English- 
language studies on Wolfram, see Hasty, ed., 1999; for the foundation of research on Wolfram, see Bumke, 2004).

The essential irony of Wolfram's Parzival consists of the protagonist's constant endeavor to forge his way through life and missing the goal repeatedly, leaving behind a stream of blood, or dead people. He is, from the beginning, the predestined successor to the Grail throne at Castle Munsalvaesche, a highly mysterious kingdom somehow associated with the divine through the Grail. The present ruler, King Anfortas, is suffering from bad wounds in his groins which cause him tremendous pain which no one can solve until the future king will arrive and ask the basic question regarding his suffering. Anfortas had failed at one point in his role as the ruler of the Grail by way of pursuing an illicit love affair. No one, however, neither a physician nor a magician, and also no worthy knight can help him until Parzival appears on the stage.

However, the young man is much too immature to understand the expectations of him, especially because he had received some basic education from the knight Gurnemanz. The latter had instructed him in the fundamentals of courtly behavior, which also entailed not to ask anything until one was invited to do so. Parzival, following those rules, observes the spectacle of the Grail procession, the miracle of the magically decked dinner table, perceives Anfortas's suffering, but he holds back from asking the long-awaited question and simply goes to sleep, which constitutes a catastrophe for himself and especially the Grail kingdom.

Already at King Arthur's court, the young man had performed poorly, demanding another knight's armor, which was granted to him as a kind of mockery. Being very good in throwing his javelin, a very uncouth weapon for an emerging knight, he manages to kill this red knight, Ither, and thus to take over his armor, and also identity, so to speak, always appearing in the red armor. The next stage in his life, Castle Munsalvaesche, also proves to be a complete failure for him, and for the rest of the romance, Parzival pursues the goal of retracing the path to the Grail. In this regard, we could call this romance a "Bildungsroman" avant la lettre, especially because Parzival has to grow in his character, has to embrace the ethical ideals of his society, and perform accordingly, which he ultimately succeeds in doing, but not without having cause much suffering and frustration, if not despondency.

Nevertheless, Parzival commands the ideals, and the good character which at the end entitle him to return to the Grail castle and then, finally, to ask the crucial question, which represents a fundamental act of communication, a topic which is certainly of central concern for world literature throughout time (Classen, 2010; Sell, 2011). He is a person with strong feelings and a firm set of ethical ideals, which finds a moving expression in one particular episode when he is traveling on his way back to his mother - by that time already long dead, without him knowing it. Parzival has left behind his beloved wife Condwiramurs and is now arriving one early morning - he had to spend the night in nature - near the location of King Arthur's court. He is unaware of that camp, and only notices a spot where, by an odd natural occurrence, snow had fallen. Shortly before his arrival, a falcon had tried to catch and kill and goose, but missed its prey. Nevertheless, the falcon hurt the goose, so three drops of blood stain the purely white snow. When the protagonist witnesses this scene, he falls into a trance, being reminded of his wife he is longing for. At the same time, the three drops carry a deep religious and philosophical meaning, as Joachim Bumke has alerted us already (Bumke, 2001) because the protagonist is suddenly in a position to transcend his material or physical existence and to gaze into the depth of all of human life. He might think only of his love, but we cannot exclude that he is also, secretly, contemplating God, of whom he still does not know much, and he is in greatest need of extensive teachings later on, due to the fact that there are three drops, which consist of blood, imprinted on the virginal white snow, and this at the time of May, the season of King Arthur's court festivals. It is worth here to quote the critical passage: 
When he saw the drops of blood on the snow - which was entirely white - he thought: 'Who has turned his skill to these bright colours? Condwiramurs, truly, theescolours resemble you! God desires to enrich me with blessings, since I have found your likeness here. Blessed by God's hand and all His Creation! Condwiramurs, here lies your semblance, since the snow has offered whiteness to the blood, and that makes the snow so red. . . . It was true love he felt for her, entirely without deviation. He so immersed himself in those thoughts that he halted there, unconscious. Mighty love held sway over him there, his wife causing him such distress. These colours bore a likeness to the Queen of Pelrapeire's person - she it was who plucked his wits from him. (Book VI, p. 119)

Whereas the young courtier at Arthur's court, Segramors, and then the more experienced, but certainly morose and selfish steward Kay utterly fail in trying to get the stranger parking outside of the camp into a joust - Parzival simply overcomes them and throws them off their horses before he quickly returns to his deep reflections - the noble and highly cultured Gawain, King Arthur's nephew, understands the situation, covers the snow with a Syrian head-scarf and can thus awaken Parzival from his dream-like absorption. Subsequently, the two men ride back to Arthur's court, so both knighthood and chivalry seem to be restored to the fullest extent. But while worldly happiness appears to be flourishing again, the real path through life for Parzival has not yet been found. In fact, the so-called 'Wheel of Fortune' (Boethius) then turns again, with the Grail messenger Cundrie appearing at the very moment when the festivities are at their best, exposing Parzival's failure at the Grail castle and thus condemning him to another long tour on his quest to redeem himself and to regain the grace to return to Munsalvaesche to ask finally the long-awaited question.

But the reputation of the Arthurian court is also badly damaged because Gawan is then equally challenged and accused of having committed a serious transgression against another knight. That means, both protagonists have to depart from there and embark on their individual quest, which then occupies the second half of the entire romance. But their paths diverge from each other. Whereas Parzival's heart is completely occupied with love for his wife Condwiramurs, who at the end, once he has asked the liberating question, is allowed to join him again, along with their two young children, Gawan falls in love with the haughty Orgeluse and needs to pursue her with all of his might, even at the risk of losing his life. However, Gawan is equally successful, achieving his goals with aplomb, although he is badly hurt during the challenge that he is facing at a castle which liberates scores of noble ladies from captivity resulting from the workings of a magician. Gawan finally wins Orgeluse's love, and Parzival, after having encountered his Muslim half-brother, Feirefiz, is granted the privilege to return to Munsalvaesche and there to reignite the foundational mechanisms of human communication.

The romance concludes with happiness ruling supreme, both for the Arthurian and the Grail kingdom, which we can easily translate into the secular and the sacred dimensions in human existence. But those triumphs are only possible because both knights, shining stars within their own respective societies, accept the charge to pursue their goals with all their might, overcoming all resistance, especially the own inner weaknesses and shortcomings. Wolfram projects a world of optimism and hope because, despite all problems, even existential crises, the knightly and the spiritual efforts by both protagonists prove to be sufficient in meeting the expectations. They redeem their respective worlds and demonstrate through their actions how we as individuals, as members of our societies, can proceed effectively and 
constructively, contributing to the growth of our world toward a spiritual fulfillment (Keyes, 2006). As Margaret Schlauch has observed regarding courtly romance, which certainly applies to Wolfram's Parzival as well, that "the knightly class found the mirror in which it liked to believe its best traits were reflected" (Schlauch 1956/1967, 184). Although there are many evil characters and truly bad moments, both in the world of King Arthur and in the Grail kingdom, the purpose of those medieval narratives was "to ennoble human conduct" (191).

Indeed, we could draw from many different other courtly romances (Erec, Yvain, by Chrétien de Troyes; Daniel von dem Blühenden Tal, by The Stricker, etc.) if we wanted to identify evilness at play and goodness fighting against it. Ultimately, however, both in Parzival and in many other romances, such as the anonymous Sir Gawain and the Green Knight (ca. 1370) or Chaucer's Troilus and Criseyde (ca. 1380), there is a clear path toward the one goal, overcoming personal shortcomings, character flaws, moral debasement, and other conflicts and problems, and then following the right direction toward honor, dignity, spiritual values and ideals, hope, and faith.

The particular quality of Wolfram's Parzival, however, seems to rest in the fairly light tone of voice, the presence of irony and satire, narrative wit, and laughter, even when a most religious ceremony is performed (Laughter in the Middle Ages). As much as we are supposed to admire the title-giving hero, who proves to be the right choice as the designated successor to the Grail throne, we are also invited to enjoy the presence of his half-brother, Feirefitz, who fully embraces Parzival as a most worthy family member and proves to be a rather jovial, happy fellow. He falls in love with the Grail maid, Repanse de Schoye, but he must first accept conversion to Christianity and baptism before he can see the Grail and hence recognize the truth of the mysterious vessel with its epitaph. The courtly company bursts out in heartfelt laughter when they realize that he is more than willing to abandon his old faith and to accept the new one so that he can marry Repanse: "The host laughed much at that, and Anfortas still more. 'If you can receive baptism thus,' said the host, 'I shall bring her close, by means of true baptism, to your command"' (Book XVI, ch. 815, p. 341).

There is a human touch to the entire conclusion of Wolfram's Parzival, and this not only because of Feirefiz's joyful acceptance of whatever the Grail community asks of him. Parzival himself is granted greatest happiness when his wife joins him again after years of involuntary separation, and brings their two little sons with her, which awaken deep fatherly feelings in Parzival, the new Grail king. At the same time, in the children's encounter with their uncle, the entire issue of racism is simply put to rest through laughter and happiness:

They all welcomed the queen, and the host and his son. Then they carried Loherangrin to his uncle Feirefiz. He being black and white, the boy did not want to kiss him. Even today, fear is reported of noble children. At that the heathen laughed. Then thos in the courtyard began to disperse, the queen having dismounted. (Book XVI, ch. 805 to 806, p. 337)

All this on top of many facetious comments by the narrator about himself, either ironical or satirical, while the entire romance is framed by a highly sophisticated narrative framework, which is often hard to decipher at first sight, especially because of the multiplicity of voices whom Wolfram gives considerable room in his romance, a phenomenon which Arthur Groos, for instance, has identified as heteroglossia in the wake of Mikhail Bakhtin's concepts (Groos, 1995, 18-19, et passim). In fact, both the overall structure of this romance and the internal concept of the quest suggest in many ways that here we face, so to speak, a novel that seems to correspond intriguingly to concepts typical of post-modernity. 
Focusing one more time on Parzival himself, the long-time wanderer whose life represents the universal human quest for truth and wisdom, we recognize from early on that he is not simply a tabula rasa, but rather a young person who possesses a warm heart, feelings for other creatures, such as the birds which his mother has killed to alleviate any possible pain in her son's soul (Book III, ch. 118-19, p. 51), or feelings for poor victims at court who have to suffer at the hand of the steward Kay because of their reactions to the protagonist in his rough appearance in front of King Arthur. Cunneware, for instance, had sworn never to laugh again until she would espy the future savior of the Grail kingdom. Confronted by Parzival, she breaks out in laughter, maybe involuntarily, but certainly prophetically, which incenses Kay so much that he beats her badly. In his typically metaphorical speech, the narrator describes it as follows: "No oath was taken on her back, yet a staff was so applied to it that, by the time its swishing had all died away, it had cut through her clothing and her skin" (Book III, ch. 151, p. 65). Young and foolish Parzival is the only one to observe this and another brutal scene with pity and deep feelings for the innocent victims, which clearly signals his inner sense of justice and compassion:

The young Parzival had no choice then but to watch these troubles befall Antanaor and the lady. Their distress touched him to the heart. Time and again he reached for his javelin - there was such a crowd before the Queen that he refrained from the throw. (Book III, ch. 153, p. 65)

We can also not forget his great empathy for the badly wounded and pained Grail King Anfortas, but again he is too young at that point to intervene as would be expected from him, at least at Castle Munsalvaesche, whereas his first teacher Gurnemanz had taught him the firm lesson not to ask a question without having been encouraged to do so (Book III, ch. 170-71, p. 73; and, for the Grail scene, Book V, ch. 239-40, p. 101).

Despite all of his shortcomings and outright failures, which often lead to other people's suffering, Parzival is projected as a representative of the human journey, repeatedly falling down, getting up, moving forward irrespective of all the hurdles. This is the case withthe lady Jeschute, for instance, whose husband Orilus immediately suspects her, having returned from a joust, of having committed adultery with the young stranger, although the foolish Parzival had just arrived from his mother's sylvan retreat and had only wanted to get food from her. Jeschute was overwhelmed by Parzival, but he had had no sexual interest in her, and yet the poor woman is subsequently badly abused by Orilus as a punishment for falsely perceived transgression on her part (Brackert, 1989).

Although it might be difficult for the non-expert to follow all those narrative details, it should have become absolutely clear what the poet Wolfram intended to achieve with his romance, which in turn explains why this medieval work continues to speak to us in many different ways, as illustrated, for instance, by modern literary adaptations (cf. Muschg's novel Der Rote Ritter, 1993). The protagonist proves to be a very different person than his father. Whereas Gahmuret was a very selfish, egocentric knight who ignored the needs of all others and struggled only for his own interests, his son possesses a warm heart, feels pity for innocently suffering birds, women, and other members of the court, and yet has to endeavor for a long time to discover the right path toward his true goal.

For Gahmuret, there was no need to question his own existence; he just lived for his own sake, aiming for fame and glory, and then passed away without having left a real heritage, 
apart from his son Parzival. The latter, by contrast, embarks on a passage throughout his life, fails numerous times to uphold the expected norms, hurts other people, but grows during the entire process and is finally, also helped by the teachings of his uncle Trevrizent, allowed, apparently by God's grace, to return to the Grail castle, ask the long-awaited question, which then releases Anfortas from his pain and thus also from his duties as a king.

Parzival then ascends to the Grail throne and re-establishes, although only loosely outlined or sketched, a new world harmony which also includes other races (such as his motelyskinned brother Feirefiz) and religions. We could perhaps go so far as to identify Wolfram's Parzival as a very early type of utopian project in literary terms.

\section{Final Observations and Conclusion}

There would be countless other texts from the Middle Ages and the early modern age through which we could demonstrate the great relevance of the past for our present and future. There is the huge corpus of mystical literature (Hildegard of Bingen, Elisabeth of Schönau, Mechthild of Magdeburg, Catherine of Siena, Julian of Norwich, Margery Kempe, Theresa of Avila, etc.), where the individual writers reflect on their personal, intimate encounters with the Godhead in a spiritual, revelatory manner (Szarmach, ed., 1984; Alexander Magee, ed., 2016). We could also draw from a large number of allegorical poems, such as Guillaume de Lorris's and Jean de Meun's Roman de la rose (ca. 1230, for Guillaume; ca. 1260 for Jean) or William Langland's Piers Plowman. If we wanted to explore responses to death, which an individual can defeat in a debate, winning at least honor in that process, we could turn to the dialogue poem by the Czech-German poet Johannes of Tepl, The Plowman, ca. 1400 for profound illuminations, whereas both Boccaccio (Decameron, ca. 1350) and Chaucer (The Canterbury Tales, ca. 1400) reflected on a wide range of human experiences and make us laugh and cry about common failures and shortcomings. Wherever we turn, pre-modern poets and authors prove to be highly meaningful for us as well, and they promise to enrich our own experience today through the presentation of ideas, values, concepts, and examples of human life. Not that much has changed in our emotional household; we continue to laugh, to hate, to fear, or to desire (Fudge, forthcoming).

Any closer analysis of medieval European literature impressively demonstrates the timeless messages contained in it. Most importantly, as we can now claim with solid evidence in our hands, the universal quest for meaning in life emerges as one of the central motifs in those texts, most relevant for us especially because of the fundamental insights expressed both in lyric poetry (Guillaume le Neuf, Walther von der Vogelweide, Christine de Pizan, etc.) and in courtly romances, both in philosophical treatises and in fable literature. As a conclusion, we can thus observe that there are a number of fundamental concerns in all of human life, such as love, death, meaning, relevance, and the spiritual dimension universally shared, and the more we become trained to look backward, the more we will also gain insights into future issues facing us all.

While we live, we all try to address those aspects and come to terms with them, as difficult as they might be. In fact, we could define life by this very struggle to find answers to those questions. However, we are not alone, and we do not need to reinvent the proverbial wheel. Wisdom from the past stands ready for all of us to inform our own existence today, and to guide us toward the future. Of course, contemporary challenges also need contemporary answers, but in ethical, moral, religious, and philosophical terms, we are blessed today by having direct access to an enormous treasure trove of ideas, insights, lessons, and values from the past that will never lose their relevance for us. In this regard, the Humanities matter critically in all of human life by opening up the communicative channels to ancient, medieval or early modern voices that can correspond easily with demands of the present or the future. This does not mean at all that we would have to idealize the past and dismiss the present; far 
from me. By the same token, we would be ill-advised to turn a blind eye toward the past and hence toward our roots. As I indicated above, almost every word that we utter reminds us of our previous cultures and the history of our identity.

Consequently, to sum up the results of this investigation, the purpose of this paper was to serve as a reminder that we are historical beings after all and that we exist within at least two axes, one horizontal (present) and one vertical (past). The more we learn how to operate on both, the better we will be prepared to discover ourselves and to move forward in our own intellectual, spiritual development and growth. The world of medieval and early modern fable literature would be another powerful example for the validity of this global claim (Classen, 'Zeitlose Lebenslehren', forthcoming), and there are many other genres that continue to appeal to us profoundly (Classen, 'Literature Is Us', forthcoming).

\section{References}

Alexander Magee, Glenn., (Ed.). (2016). The Cambridge Handbook of Western Mysticism and Esotericism. New York: Cambridge University Press.

Arnold, John H. (2021). What is Medieval History? 2nd ed. What is History? Series. Cambridge: Policy Press.

Banner, James M. (2012, Jun). Being Historian: An Introduction to Professional World of History. Cambridge: Cambridge University Press.

Barclay, Katie. (2020). The History of Emotions: A Student Guide to Methods and Sources. London: Bloomsbury.

Boethius. (1969). The Consolation of Philosophy. Trans. with an intro. V. E. Watts. London: Penguin.

Brackert, Helmut. (1989). “der lac an riterscheftetôt”: Parzival und das Leid der Frauen.' In Rüdiger Krüger, Jürgen Kühnel, and Joachim Kuolt (Eds.)., Ist zwîvel herzen nâchgebûr: Günther Schweikle zum 60. Geburtstag (pp. 143-63). Helfant Studien, S 5. Stuttgart: Helfant edition.

Breisach, Ernst. (2003). On the Future of History: The Post Modernist Challenge and Its Aftermath. Chicago: University of Chicago.

Broomhall, Susan., (Ed.) (2017). Early Modern Emotions: An Introduction. London and New York: Routledge.

Bumke, Joachim. (2001). Die Blutstropfen im Schnee: Über Wahrnehmung und Erkenntnis im 'Parzival' Wolframs von Eschenbach. Hermaea. Germanistische Forschungen, Neue Folge, 94. Tübingen: Max Niemeyer.

Bumke, Joachim. (2004). Wolfram von Eschenbach. 8th, compl. rev. ed. Stuttgart and Weimar: Metzler.

Calabrese, Michael. (2020). William Langland. Piers Plowman: The A Version. A new trans. with intro. and notes. Washington, DC: The Catholic University of America Press.

Carr, Edward Hallett. (1961). What is History?: The George Macaulay Trevelyan Lectures Delivered in the University of Cambridge, Jan.-March 1961. London: Macmillan.

Classen, Albrecht. (2010). Communication in the Middle Ages. In Albrecht Classen (Ed.), Handbook of Medieval Studies: Terms - Methods - Trends, vol. 1 (pp. 330-43). Berlin and New York: Walter de Gruyter.

Classen, Albrecht., (Ed.). (2010). Laughter in the Middle Ages and Early Modern Times: Epistemology of a Fundamental Human Behavior, Its Meaning, and Consequences. 
Fundamentals of Medieval and Early Modern Culture, 5. Berlin and New York: Walter de Gruyter.

Classen, Albrecht. (2016). The Erotic and the Quest for Happiness in the Middle Ages. What Everybody Aspires to and Hardly Anyone Truly Achieves. In Ian Moulton (Ed.), Eroticism in the Middle Ages and the Renaissance: Magic, Marriage, and Midwifery (pp. 1-33). Arizona Studies in the Middle Ages and the Renaissance, 39. Tempe, AZ, and Turnhout, Belgium: Brepols.

Classen, Albrecht., (Ed.). (2017). Medieval Answers to Modern Problems, 2nd rev. ed. (orig. 2012). San Diego: Cognella, University Readers.

Classen, Albrecht. (2017). The Challenges of the Humanities, Past, Present, and Future: Why the Middle Ages Mean So Much For Us Today and Tomorrow. Thalloris 2, 191-217.

Classen, Albrecht. (2018). The Human Quest for Happiness and Meaning: Old and New Perspectives: Religious, Philosophical, and Literary Reflections from the Past as a Platform for Our Future: St. Augustine, Boethius, and Gautier de Coincy. Athens Journal of Humanities \& Arts 5(2), 179-206. (http://www.athensjournals.gr/humanities/2018-5-2-3-Classen.pdf).

Classen, Albrecht. (2020). 'The Amazon Rainforest of Pre-Modern Literature: Ethics, Values, and Ideals from the Past for our Future. With a Focus on Aristotle and Heinrich Kaufringer', in Humanities Open Access 9(1). 4, online at: file:///C:/Users/aclassen/Downloads/humanities-09-00004.pdf.

Classen, Albrecht. (2021). Happiness - Pre-Modern Answers for Questions Today from Boethius to Fortunatus. Current Research Journal of Social Sciences and Humanities 4(1). https://bit.ly/31JArCR.

Classen, Albrecht. (2021). Music as a Universal Bond and Bridge Between the Physical and the Divine: Transcultural and Medieval Perspectives. Rupkatha Journal on Interdisciplinary Studies in Humanities 13(3), 1-30. https://rupkatha.com/V13/n3/v13n301.pdf; or: DOI: 10.21659/rupkatha.v13n3.01.

Classen, Albrecht. (2021). Tracing the Trails in the Medieval World: Epistemological Explorations, Orientation, and Mapping in Medieval Literature. Routledge Studies in Medieval Literature and Culture. New York and London: Routledge.

Classen, Albrecht. [Forthcoming]. Literature Is Us and We are Literature: Global and Universal Perspective. Journal of Language, Literature and Culture.

Classen, Albrecht. [Forthcoming]. Zeitlose Lebenslehren aus dem Spätmittelalter: die Fabeln des Ulrich Bonerius, Der Edelstein (ca. 1350), ein literarisches Juwel aus der Vergangenheit für uns heute. Oder: Warum ist das Mittelalter relevant für uns heute: ethische, moralische und pragmatische Reflektionen. In Vergangenheit-GegenwartZukunft. Mediävistische Perspektiven im 21. Jahrhundert: Festschrift Ingrid Bennewitz, ed. Andrea Schindler.

Contreras-Vejar, Yuri, Joanna Tice Jen, and Bryan S. Turner., (Eds.). (2019). Regimes of Happiness: Comparative and Historical Studies. London: Anthem Press.

Dagenais, John and Margaret R. Greer. (Fall 2000). Decolonizing the Middle Ages: Introduction. Journal of Medieval and Early Modern Studies 30(3), 431-48.

Davetian, Benet. (2019, orig. 2017). Civility: A Cultural History. Toronto: University of Toronto Press.

Dinzelbacher, Peter., (Ed.). (2008, orig. 1993). Europäische Mentalitätsgeschichte: Hauptthemen in Einzeldarstellungen. Kröners Taschenausgabe, 469. 2ndrev. ed. Stuttgart: Alfred Kröner.

Ehrismann, Otfrid. (2008). Einführung in das Werk Walthers von der Vogelweide. Einführungen Germanistik. Darmstadt: Wissenschaftliche Buchgesellschaft.

Feyerabend, Paul. (1989). Realism and the Historicity of Knowledge. The Journal of Philosophy 86(8), 393-406. 
The Past, the Present, and the Future: Memory and Literature as Gateways from the Middle Ages to the Twenty-First Century With a focus on Boethius's De Consolatione Philosophiae and

Fudge, Thomas. [Forthcoming]. Laughing, Crying and Killing: Emotions at Stake in Medieval Bohemia. Mediaevistik, 34.

Groos, Arthur. (1996). Romancing the Grail. Genre, Science, and Quest in Wolfram's Parzival. Ithaca, NY, and London: Cornell University Press.

Hartmann, Heiko. (2015). Einführung in das Werk Wolframs von Eschenbach. Einführungen Germanistik. Darmstadt: Wissenschaftliche Buchgesellschaft.

Hasty, Will., (Ed.). (1999). A Companion to Wolfram's Parzival. Studies in German Literature, Linguistics, and Culture. Columbia, SC: Camden House.

Heng, Geraldine. (2018). The Invention of Race in the European Middle Ages. New York and Cambridge: Cambridge University Press.

Kaplan, M. Lindsay. (2019). Figuring Racism in Medieval Christianity. New York: Oxford University Press.

Keyes, Flo. (2006). The Literature of Hope in the Middle Ages and Today: Connections in Medieval Romance, Modern Fantasy, and Science Fiction. Jefferson, NC, and London: McFarland.

Kohen, Ari and Gerald J. Steinacher., (Ed.). (2021). Antisemitism on the Rise: The 1930s and Today. Contemporary Holocaust Studies. Lincoln, NE: University of Nebraska Press.

Kydd, D. C. and E. Castano. (2013). Reading Literary Fiction Improves Theory of Mind. Science 342(6156), 377-380.

Marenbon, John., (Ed.). (2009). The Cambridge Companion to Boethius. Cambridge Companions to Philosophy. Cambridge: Cambridge University Press.

Moor, Robert. (2016). On Trails. New York, London, et al.: Simon \& Schuster.

Muschg, Adolf. (1993). Der rote Ritter: Eine Geschichte von Parzival. Frankfurt a. M.: Suhrkamp Verlag.

Oatley, K. (2016). Fiction: Simulation of Social Worlds. Trends Cognitive Sciences 20(8), 618-28.

Powell, James M. (2016, orig. 1992). Albertanus of Brescia: The Pursuit of Happiness in the Early Thirteenth Century. The Middle Ages Series. Philadelphia, PA: University of Pennsylvania Press.

Reichert, Hermann. (2009, orig. 1992). Walther von der Vogelweide für Anfänger. 3rd, completely rev. and expanded ed. Vienna: facultas.wuv.

Rosenwein, Barbara H. and Riccardo Cristiani. (2018). What is the History of Emotions? Cambridge: Polity.

Santayana, George. (1905-1906). The Life of Reason: The Phases of Human Progress. 5 vols. New York: C. Scribner's Sons.

Schlauch, Margaret. (1967, orig. 1956). English Medieval Literature and Its Social Foundation. London: Oxford University Press.

Sell, Roger D. (2011). Communicational Criticism: Studies in Literature as Dialogue. Dialogue Studies11. Amsterdam: Benjamin.

Seth, Vanita. (2020). The Origins of Racism: A Critique of the History of Ideas. History \& Theory 59(3), 343-68. DOI: 10.1111/hith.12163.

Southern, R. W. (2004). History and Historians: Selected Papers of R. W. Southern. In R. J. Bartlett (Ed.), Malden, MA, Oxford, and Carlton, Victoria: Blackwell.

Szarmach, Paul E., (Ed.). (1984). An Introduction to the Medieval Mystics: Fourteen Original Essays. Albany, NY: State University of New York Press.

Walther von der Vogelweide. (2003). The Single-Stanza Lyrics. Ed. and trans. with intro. and commentary by Frederick Goldin. New York and London: Routledge.

Walther von der Vogelweide. (2013). Leich, Lieder, Sangsprüche. 15th, revised and expanded edition of the edition by Karl Lachmann, Thomas Bein (Ed.), on the basis 
of the 14th ed. prepared by Christoph Cormeau. Berlin and Boston: Walter de Gruyter.

Wolfram von Eschenbach. (1998). Parzival, ed. Karl Lachmann. 6th ed. Trans. into modern German by Peter Knecht. Intro. by Bernd Schirok. Berlin and New York: Walter de Gruyter.

Wolfram von Eschenbach. (2004/2006). Parzival und Titurel. Trans. Cyril Edwards. Oxford: Oxford University Press.

Zunshine, L. (2006). Why We Read Fiction: Theory of Mind and the Novel. Columbus OH: Ohio State University Press.

\section{$\underline{\text { Bio-note }}$}

Dr. Albrecht Classen is University Distinguished Professor of German Studies at the University of Arizona, Tucson, where he is researching and teaching medieval and early modern literature and culture, with a strong interest also in creative writing, poetry, and contemporary literature (he is the current President of the Society for Contemporary American Literature in German, SCALG). He is also the Director of, Summer Abroad Program, Medieval Europe Travel Course. He was nominated for the "Global Excellence Service Award," University of Arizona. He has published close to 115 scholarly books and more than 760 articles. His current research focuses on freedom, imprisonment, and slavery in the pre-modern world (a book appeared under that title in 2021). Among his other recent books are Tracing the Trail in the Medieval world (2020), The Myth of Charlemagne (scharle men) in Medieval German and Dutch Literature (2020), Religious Toleration in the Middle Ages and Early Modern Age, and many more. He is the editor-in-chief of journals Mediaevistik and Humanities and also the Editor for academia.edu (online) and Series Editor, Renaissance and Baroque, German Literature.

Email Id: aclassen@email.arizona.edu 